\title{
Peran Kearifan Lokal Masyarakat Dayak dalam Mengembangkan Batik Benang Bintik di Kalimantan Tengah
}

\author{
Linggua Sanjaya Usop", Tari Budayanti Usop² \\ ${ }^{1}$ Fakultas Keguruan dan Ilmu Pendidikan, Universitas Palangka Raya, Jalan H. Timang, Palangka Raya \\ ${ }^{2}$ Fakultas Teknik Arsitektur, Universitas Palangka Raya, Jalan H. Timang, Palangka Raya

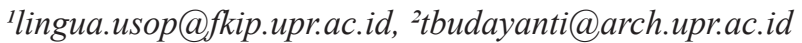

\begin{abstract}
Kegiatan yang menghasilkan nilai filosofi tinggi pada batik masih belum maksimal oleh masyarakat pembuatnya yakni para perajin batik. Fenomena minimnya pengetahuan tentang jenis, motif, dan pakem penggunaanya oleh pengusaha batik lokal dalam pembuatan batik benang bintik di sentra-sentra batik merupakan masalah yang harus dipecahkan dari berbagai latar belakang, di antaranya secara sosial dan budaya. Solusi dan alternatif pemecahan masalah dengan menggunakan konsep kearifan lokal yang diterapkan kembali oleh para perajin batik di kalimantan tengah. Rumusan masalah penelitian antara lain: 1) apa faktor yang menyebabkan minimnya pengetahuan tentang pembuatan dan fungsi batik tradisi di kalimantan tengah?, 2) apa peran kearifan lokal masyarakat Dayak di kalimantan tengah untuk melestarikan batik benang bintik?, dan 3) bagaimana cara penerapan kearifan lokal masyarakat Dayak di kalimantan tengah?. Metode etnografi dipergunakan dalam penelitian ini. Teori kebudayaan superorganik dari Melville J. Herkovits dipergunakan untuk menemukan korelasi antara peran kearifan lokal dengan pelestarian batik benang bintik. Teknik pengambilan data yakni wawancara mendalam pada para perajin batik di kalimantan tengah, tokoh, dan pakar batik sebagai data primer; serta studi pustaka referensif sebagai data sekunder. Pendekatan antropologis dipergunakan sebagai instrumen analisis berdasarkan realitas sosial dan budaya. Penelitian ini menemukan bahwa peran kearifan lokal masyarakat Dayak dalam mengembangkan dan melestarikan batik benang bintik di Kalimantan Tengah dapat berjalan efektif melalui dukungan pendidikan pranata sosial seperti keluarga dan universitas secara intensif.
\end{abstract}

Kata kunci: batik benang bintik, kalimantan tengah, kearifan lokal, masyarakat dayak

\section{The Role of Local Wisdom of the Dayak Community in Developing Batik Benang Bintik in Central Kalimantan}

Activities that produce high philosophical values in batik are still not maximal by the craftsman who make it. The phenomenon of the lack of knowledge about the types, motifs, and standards of the use of local batik producers in making benang bintik batik in batik sales centers is a problem that must be solved from various perfectives, including socially and culturally. The solutions and alternative solutions to problems using the approached of local wisdom are re-applied by batik craftsmen in Central Kalimantan. The problems of study include: 1) what are the factors that cause the lack of knowledge about the making and function of traditional batik in Central Kalimantan? 2) what is the role of the local wisdom of the Dayak community in Central Kalimantan to preserve the batik benang bitnik? And, 3) how to apply the local wisdom of the Dayak community in Central Kalimantan. Ethnographic approach was used in this study. The Melville J. Herkovits' theory of superorganic culture was used to find a correlation between the role of local wisdom and the preservation of batik benang bintik. Data collection techniques, using in-depth interviews with batik craftsmen, figures, and batik experts in Central Kalimantan as primary data; literature study as secondary data. The anthropological approach is used as an analytical instrument based on social and cultural realities. This study found that the role of local wisdom of the Dayak community in developing and preserving batik benang bintik in Central Kalimantan can be carried out effectively through intensive educational support for social institutions such as family and university.

Keywords: batik benang bintik, central kalimantan, dayak community, local wisdom.

Proses Review : 1 - 30 Juni 2021, Dinyatakan Lolos: 27 Juli 2021 


\section{PENDAHULUAN}

Salah satu bentuk dari wujud kebudayaan adalah kearifan lokal masyarakat atau yang sering disebut pengetahuan masyarakat lokal. Kearifan lokal merupakan representasi dari nilai-nilai budaya lokal khususnya yang dalam tulisan ini berkenaan dengan budaya lokal (batik benang bintik) dalam kebudayaan Dayak Ngaju. Inti dari kebudayaan adalah nilai-nilai budayanya (core values), maka tidak dapat dipungkiri lagi bahwa nilai-nilai merupakan patokan penilaian atau pedoman etika dan moral serta menginterpretasikan tindakan menurut kebudayaan setempat. Isi dari kebudayaan itu di dalamnya terdapat pengetahuan lokal (local knowledge) yang terselubung di dalam makna dan pesan yang diwakili dengan adanya tanda-tanda yang berupa kata-kata, pepatah-petih, ungkapan-ungkapan, nyanyian, semboyan, dan literatur sastra yang melekat dalam perilaku warga masyarakat Dayak dalam mengelola lingkungan alamnya dalam usaha untuk memenuhi kebutuhan hidup.

Kearifan lokal memiliki hubungan yang erat dengan kebudayaan tradisional pada suatu tempat, dalam kearifan lokal tersebut banyak mengandung suatu pandangan maupun pedoman agar masyarakat lebih memiliki acuan dalam menentukan suatu tindakkan seperti prilaku masyarakat sehari-hari. Pada umumnya isi kebudayaan baik berupa konsep-konsep, moral, dan etika yang terkandung dalam kearifan lokal diajarkan turun-temurun, diwariskan dari generasi ke generasi secara lisan dan manuskrip. Kearifan lokal yang diajarkan secara turuntemurun tersebut merupakan kebudayaan yang patut dijaga, masing-masing wilayah memiliki kebudayaan sebagai ciri khasnya dan terdapat kearifan lokal yang terkandung di dalamnya.

Produk budaya merupakan identitas daerah yang mampu merepresentasikan budaya. Indonesia telah diakui sebagai negara dengan kekayaan dan keragaman produk budaya yang masing-masing memiliki makna filosofis. Nilai dan norma sebagai pedoman hidup bagi masyarakat merupakan referensi pembentuk keragaman produk budaya (Suparlan, 2003). Serangkaian nilai dan norma tersebut bersifat dinamis, mampu menyesuaikan zaman yang memiliki keniscayaan untuk tumbuh, berkembang, dan berubah. Masyarakat memiliki kecenderungan untuk mengikuti perubahan zaman dan mengkonsumsi hasil perkembangannya, yakni teknologi. Tatanan masyarakat dan seluruh aspek pendukungnya mengalami perubahan karena kemajuan teknologi, terlebih di zaman yang disebut revolusi industri 4.0 saat ini. Peran manusia tereduksi oleh mesin, kecerdasan buatan, dan sistem digital. Muncul istilah disrupsi yang beriringan dengan revolusi industri 4.0 saat ini. Kegagalan manusia untuk mengelola posisi dan tetap berdaya di zaman posmodern yang serba cepat adalah penyebab disrupsi. Masyarakat dituntut untuk kreatif, mampu bertahan dengan panduan hidup yang sesuai, dan memanfaatkan kecanggihan teknologi secara cerdas. Mereka yang mampu mengkombinasikan antara konsep, kreatifitas, ketekunan, dan kerja cerdas dengan bijak yang akan memenangi persaingan. Kebijaksanaan yang dapat dijadikan pedoman dan panduan terdapat pada kearifan lokal (Situngkir, 2016).

Abstraksi konsep masyarakat tradisi sebagai panduan cara hidup bersumber dari kebijaksanaan (kompromi kontemplatif hasil perenungan mendalam) dan kebijakan (ketetapan dari kesepakatan) leluhur yang disebut kearifan lokal (Endraswara, 2018). Esensi kearifan lokal yang dipahami masyarakat tertuang dalam tiga wujud, yakni mentifak (pola pikir), sosiofak (norma dan nilai dalam masyarakat), dan artefak (benda pendukung kebutuhan hidup) dalam hal ini batik. Tiga hal tersebut saling terkait, terhubung, dan berkorelasi. Pola pikir dan norma yang diyakini oleh sebuah masyarakat dapat terlihat dari wujud artefaknya. Sebaliknya, artefak merupakan petunjuk norma dan pola pikir yang diyakini oleh suatu masyarakat (Tabrani, 2012: 16-22, 178-184). Masyarakat yang tinggal di Daerah Aliran Sungai (DAS) memiliki karakter dan wujud artefak berbeda dengan masyarakat di dataran rendah dan di pegunungan. Kondisi alam, iklim dan geografis secara alami mendorong manusia untuk melakukan sistem adaptasi dan menciptakan produk budaya sebagai mekanisme pertahanan khusus. Kearifan lokal mengandung unsur solusi masalah untuk menjawab permasalahan manusia ketika menyesuaikan kondisi lingkungan. Mobilitas dan perpindahan suatu masyarakat akan membawa serta wujud kearifan lokal dan meninggalkan jejak kekhasannya, kemudian tercipta akulturasi budaya. Kearifan lokal pada artefak dominan terdapat di benda kebutuhan primer manusia, yakni sandang, pangan, dan papan; terwujud melalui proses, bentuk, nilai, corak, dan fungsi. Perubahan zaman telah merubah alur tersebut menjadi sebaliknya. Saat ini artefak digunakan sebagai perantara untuk medium pesan dan ekspresi artistik dengan material baru (Nurcahyanti, 2020). Tradisi lisan melalui bertutur dalam pengertian harfiah, menjadi cara dasar bagi manusia untuk menyampaikan pesan, petuah, dan nasehat pada pihak lain. Pada masyarakat nusantara awal sebelum Indonesia merdeka; bertutur melalui cerita dan dongeng menjadi bentuk komunikasi untuk menyampaikan pesan secara non formal dalam keluarga; kemudian terbentuk sebuah budaya tutur, bercerita, dan mendongeng. Bertutur merupakan cara berkomunikasi mudah dan alami, tetapi memiliki kelemahan. Pesan atau cerita yang disampaikan akan memiliki kualitas dan maksud yang dipahami secara berbeda, jika diulang dengan komponen berbeda. Komponen yang dimaksud adalah pelaku, gaya, irama, suasana, dan penerima pesan. Komodifikasi dan pendokumentasian diperlukan dengan tujuan pesan dapat dipelajari ulang dalam jangka panjang dengan maksud sama sebagaimana penutur pertama menyampaikan. Format tulis melalui beragam media merupakan cara 
mengabadikan tutur supaya dapat dipahami oleh generasi berikutnya tanpa mengurangi inti cerita. Beberapa pesan terabadikan dalam tradisi lisan dan lembar-lembar manuskrip atau naskah kuno. Sebagian cerita masih diwariskan dalam bentuk lisan secara turun- menurun dari generasi ke generasi, yaitu tradisi lisan (Nurcahyanti, 2020).

Masyarakat Dayak Kalimantan Tengah memiliki tradisi lisan sebagai bentuk budaya dan media dalam menyampaikan pesan; selanjutnya bertransformasi melalui beragam wujud produk budaya. Cara penyampaian pesan menggunakan pemilihan kalimat penuh simbol dan frasa-frasa, perlambang, dan kiasan. Uloh itah atau masyarakat Dayak memiliki berkarakter terbuka, sehingga cara menyampaikan pesan pun menggunakan kalimat langsung. Kelemahan cara penyampaian pesan langsung dengan cara lisan yakni suliti diingat dan bias. Pesan sulit dimengerti oleh pihak lain yang kurang paham karakter masyarakat Dayak; karena harus menginterpretasikan ulang maksud kalimat tersebut. Kelebihannya adalah mampu berkomunikasi dengan para leluhur secara simbolik. Sikap demikian merupakan bentuk kearifan lokal masyarakat yang disebut sangiang; cara menyikapi dan berkomunikasi khas Dayak yang bijaksana. Kearifan lokal menjadi panduan nilai dan norma yang penting bagi masyarakat Dayak; dan memiliki peran sebagai sarana penjaga harmoni/keseimbangan antara manusia dengan alam secara fisik serta metafisik (Usop, 2015). Batik adalah salah satu media ekspresi masyarakat Dayak dalam menyampaikan pesan secara simbolis. Motif batik benang bintik merupakan kumpulan ornamen stilasi (penggayaan) dengan komposisi estetis yang bertu juan untuk menyampaikan pesan, cerita, dan nasehat bijak.

Mengikuti Hutabarat (1999) pakaian daerah yang telah disepakati, diterima, dan dikenakan oleh sebagian besar masyarakat Indonesia yang menjadi simbol budaya bangsa disebut pakaian nasional. Salah satu pakaian nasional, menurut Hutabarat, adalah sarong batik yang digunakan sebagai pelengkap busana bagian depan dan penutup depan bagi masyarakat. Juga digunakan sebagai pelengkap bukaan depan baju atau close suit pria (Hutabarat, 1999). Penggunaan benang bintik batik sebagai pelengkap fashion ditemukan di berbagai era di Kalimantan Tengah. Sejak dulu, perubahan corak batik benang bintik dipengaruhi oleh kondisi yang populer dan berkaitan erat dengan faktor-faktor lain yang berpengaruh seperti kondisi ekonomi, politik, sosial dan budaya.

Batik benang bintik saat ini mengalami permasalahan terkait pakem dan jenis, dan penggunaan oleh generasi penerusnya; khususnya pewarisan keahlian membatik. Era keterbukaan informasi dan perkembangan teknologi telah menawarkan alternatif motif yang tidak sesuai dengan pakem dan nilai-nilai budaya. Proses batik memiliki rangkaian panjang dan detail, tidak dapat dikerjakan sambil lalu. Tahapannya harus dilalui secara baik, tidak boleh ditawar dengan mengurangi atau mengakali proses (membatik tidak berdasarkan urutan), karena akan mempengarungi kualitas serta makna keseluruhan karya. Salah satu alternatif yang dipilih oleh generasi penerus perajin batik tersebut yakni membuat batik dengan proses non manual, menggunakan mesin cetak atau digitalisasi. Proses mesin dan digital menyebabkan hasil akhir tidak dapat disebut sebagai kain batik, tetapi tekstil atau kain dengan motif batik. Kain batik adalah kain yang diberi hiasan ornamen motif batik dengan teknik tutup celup malam panas menggunakan canting atau cap tembaga. Kekhawatiran para budayawan dan pembatik senior atau yang berusialanjutcukup beralasan, karena generasipenerus tidak berminat belajar membatik atau memilih alternatif proses di luar batik tradisi untuk memvisualisasikan motifmotif batik tanpa mempertimbangkan kepedulian terhadap keberlanjutan tradisi.

Para pembatik di kota Palangka Raya merupakan sentra batik tradisi benang bintik yang mengalami masalah keragaman motif, jenis dan pakemnya serta keahlian membatik pada ragam produknya. Kesempatan pelatihan yang diberikan oleh pemerintah untuk memperdalam keahlian membatik dari segi proses, jenis dan desain motif mampu menggerakkan para pembatik untuk berinovasi mengembangkan motifbaru dan motifbatikikon untuk batik benang bintik. Hal tersebut menggerakkan para generasi penerus untuk mulai belajar membuat motif baru dan membatik. Nasehat, pesan, dan cerita bersumber kearifan lokal masyarakat Dayak menjadi inspirasi pembuatan motif kontemporer. Upaya pembatik kalimantan tengah tersebut menarik diteliti. Pembatik Kalimantan Tengah secara tidak langsung telah menciptakan solusi untuk masalah keberlanjutkan keahlian membatik. Penelitian ini bertujuan untuk mengeksplorasi cara masyarakat Dayak untuk menumbuhkan kesadaran keberlanjutan batik tradisi; dan mendiskripsikan wujud kearifan lokal yang dipergunakan sebagai sumber ide pengembangan desain motif kekinian. Kota Palangka Raya dipilih sebagai lokasi penelitian karena memiliki latar belakang pengembangan batik tradisi yang kuat sejak awal pemerintahan yakni pemimpin Gubernur Tjilik Riwut, Reinout Sylvanus, W.A. Gara, dan Soeparmanto, dan Teras Narang.

Pengembangna motif amak dare dan kearifan lokal masyarakat Dayak dalam keberlanjutan batik di Kalteng merupakan pengembangan dari penelitian terdahulu. Topik serupa masih terdapat celah permasalahan untuk dieksplorasi lebih lanjut, yakni perihal peran kearifan lokal pada suatu masyarakat untuk keberlanjutan tradisi batik. Penelitian-penelitian terdahulu telah membahas kearifan lokal masyarakat Dayak dari aspek kemanfaatannya sebagai sumber inspirasi dalam penciptaan karya seni, desain, dan panduan perumusan kebijakan pemerintah berkaitan dengan hukum; serta cara mereaktualisasi kearifan lokal dengan kondisi masyarakat terkini. Aspek 
dampak atau akibat dari penerapan lokal pada suatu masyarakat sebagai solusi permasalahan regenerasi tradisi belum pernah diteliti. Referensi terkait topik kearifan lokal, keberlanjutan (pewarisan, pelestarian), dan tradisi yang digunakan sebagai referensi penelitian terdapat pada makalah, jurnal, dan buku.

Simbol Batang Garing dan filosofis huma betang, hapakat menguraikan tentang nilai-nilai luhur yang diperoleh dengan memahami ungkapan yang sering digunakan oleh masyarakat Dayak dalam kehidupan sehari-hari. Hasil penelitian mengungkap bahwa memahami kebudayaan Dayak dan kearifan lokal dapat digunakan sebagai sumber pendidikan karakter bersifat universal. Cara pemahaman dapat diterapkan pada peserta didik dengan empat metode, yakni penanaman nilai, keteladanan nilai, fasilitasi nilai, dan keterampilan. Pada "Peranan Kearifan Lokal dalam Pendidikan Karakter" atau The Role of Local Wisdom in Character Building Education, kearifan lokal menjadi objek diskriptif secara universal di wilayah Kalimantan Tengah. Hal serupa disebutkan dalam penelitian "Kearifan Lokal sebagai Modal Sosial dalam Pendidikan Karakter di Sekolah" atau Local Wisdom as Social Capital in Character Building at School Education, dengan kebaruan pada ruang lingkup penerapan yaitu sekolah, dan posisi kearifan lokal bagi pendidikan karakter sebagai modal sosial (Astuti, 2012: 61-72).

Kearifan lokal didefinisikan secara sederhana pada temuan publikasi ilmiah berjudul "Nilai Kearifan Lokal dalam Batik Tradisional Kawung" atau Local Wisdom Values at The Kawung's Traditional Batik, yakni sebagai tatanan hidup ideal pada masyarakat yang tersirat dan tersurat pada warna, corak, pola, serta fungsi. Kedalaman makna yang terdapat pada motif batik Kawung merupakan hasil akulturasi budaya Jawa, Hindhu, dan Islam yang kaya filosofi. Peran kearifan lokal pada artikeljurnal tersebut tidak disinggung secara langsung, karena fokus permasalahan dipersempit pada nilai simbolis batik motif Kawung secara sosial dan sakral (Pramono, 2013: 134-146). Hal serupa juga menjadi pokok bahasan penelitian lain berjudul "Identifikasi Bentuk-bentuk Kearifan Lokal dalam Sistem Religi Masyarakat Situs Sangiran Studi Kasus Masyarakat Gondangrejo, Karanganyar" atau Local Wisdom Forms Identification in The Sangiran's Site Society Religion System Case Study Gondangrejo Society, Karanganyar. Penelitian tersebut menyimpulkan bahwa masyarakat Sangiran (sampai dengan penelitian diselenggarakan) masih menjaga religiusitas dan melaksanakan aktivitas tradisi sebagai simbol bentuk kearifan lokal (Amanda, 2018: 123-132). Eksplorasi kearifan lokal dalam ranah karya sastra fiksi menjadi pembahasan dari perspektif sistem pemerintahan masyarakat Jawa dalam "Kearifan Lokal Masyarakat Jawa dalam Novel Genduk Sundari Mardjuki" atau Javanese Society Local Wisdom in The Genduk Sundari Mardju- ki's Novel (Ningsih, 2018: 1-11). Nilai filosofi tinggi pada batik tradisi terletak pada fungsinya sebagai sumber ajaran pedoman hidup manusia, identitas, religiusitas, dan harmonisasi dengan alam fisik serta metafisik (Herdiana, 2020: 53-62; Qiram, 2018: 7985; Wahida, 2020: 76-82).

Batik seperti seni tradisi lain memiliki nilai filosofis yang bersifat didaktis, humanistis, dan spiritual sebagai indikator kompleksitas kultural sebuah bentuk peradaban serta cerminan suatu tatanan ideal di masyarakat (Kristie, 2019: 57-69; Suarta, 2018: 191-199; Suminto, 2015: 1-12). Batik tradisi saat ini mulai meninggalkan ajaran nilai filosofis, tercermin pada proses pembuatannya yang dilaksanakan atas dasar motif ekonomi, bukan aktivitas serta sarana spiritualitas.

Secara keseluruhan referensi makalah, jurnal, dan buku dengan topik kearifan lokal masyarakat Dayak dari berbagai perspektif masih terdapat celah topik penelitian, yakni peran kearifan lokal dalam keberlanjutan jenis, motif dan pakem penggunaanya dengan spesifikasi pada batik tradisi benang bintik. Urgensi penelitian ini adalah mengetahui dan mendeskripsikan peran keberlanjutan melalui penerapan kearifan lokal pada sebuah komunitas masyarakat untuk mengembangkan dan pelestarian batik tradisi di masa-masa pandemi COVID-19, sehingga dapat dirumuskan solusi keberlanjutannya untuk jangka panjang.

\section{METODE PENELITIAN}

Pendekatan antropologis dengan sudut pandang etnografis dipergunakan untuk mengumpulkan dan menganalisis data penelitian ini secara kualitatif. Pemilihan pendekatan tersebut berdasarkan karakter permasalahan yakni mengetahui dan menguraikan peran kearifan lokal masyarakat Dayak yang dipergunakan untuk melestarikan batik tradisi di wilayah Kalimantan Tengah. Sifat pendekatan antropologis menitikberatkan pada pengamatan terhadap perilaku dan cara berpikir masyarakat. Hal tersebut sesuai dengan tujuan penelitian ini untuk melihat upaya-upaya masyarakat Dayak di Kalimantan Tengah dalam mengembangkan dan melestarikan batik tradisi dengan sumber kearifan lokal setempat (Ihromi, 2006; Wiranata, 2011). Latar belakang pemilihan Kalimantan Tengah sebagai lokasi penelitian karena memiliki akar sejarah kuat terkait keberadaan aktifitas membatik secara tradisional (batik tradisi) di Kota Palangka Raya tersebut, yang mendapat pengaruh dari Kaharingan. Batik yang dihasilkan telah menggunakan teknik modern seperti sablon (printing), malam dingin, dan digital; tetapi masih mempertahankan proses tulis/ benang bintik/mambintik dalam bahasa daerah; sehingga motif, jenis, pakem membatik Kalimantan Tengah saat ini tengah mengalami krisis kerancuan dan kekuranang nilai keberlanjutan pembatik berusia muda yang mengetahui makna dan bentuk motif, jenis dan pakem penggunaan, kemudian berhasil bangkit perlahan dengan inisiatif para akademisi dan budayawan untuk menciptakan desain 

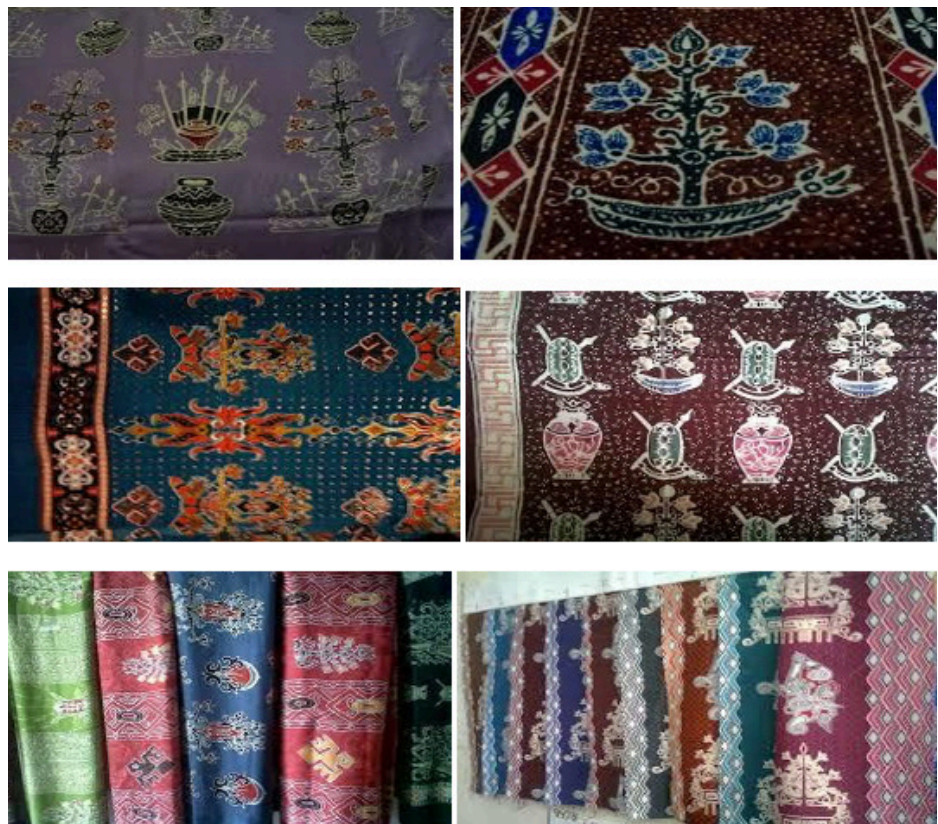

Gambar 1. Gambar beberapa motif benang bintik/motif batik khas Dayak Kalimantan Tengah

motif baru (amak dare). Unsur kearifan lokal Kalimantan Tengah tercermin pada nilai filosofis motif batik kontemporer yang dihasilkan. Masyarakat Kalimantan Tengah masih teguh memegang simbol batang garing pada motif batang garing ajaran yang berisi tentang mental untuk ikut memiliki tanggungjawab, membela atau mempertahankan keberlanjutan tradisi, serta hal-hal bersifat baik untuk kemaslahatan masyarakat luas, dan instropeksi (pengendalian diri).

Pengumpulan data dilakukan dengan teknik wawancara, observasi, dan dokumentasi. Data yang diperoleh berasal dari wawancara mendalam dengan pembatik di Kalimantan Tengah sebagai pelaku inisiasi desain motif baru. Referensi tentang pusat batik Kalimantan Tengah masih minim, sehingga wawancara dengan pelaku atau perajin batik secara langsung adalah teknik tepat untuk memperoleh data akurat. Validitas data menggunakan validitas sumber dan data. Data yang diperoleh setelah melalui proses reduksi tersebut dikroscek kembali dengan pendapat dari tokoh masyarakat, pakar batik, peneliti lain dengan topik seputar Kalimantan Tengah, dan referensi atau arsip serta dokumentasi yang relevan. Narasumber pelaku inisiasi desain motif baru dipilih berdasarkan kesepakatan kelompok, diwakili oleh pembatik yang mempraktikkan langsung proses pembuatan motif dengan sumber ide kearifan lokal Kalimantan Tengah. Wawancara tidak hanya menggali informasi seputar pembuatan motif baru, tapi juga terkait dasar penggunaan kearifan lokal Kalimantan Tengah untuk membuat motif batik baru, yang mampu menggugah semangat generasi mudah untuk melanjutkan batik tradisi. Hasil penelitian dideskripsikan sebagai jawaban dari rumusan permasalahan. Analisis referensif dilakukan dengan mencari faktor ketersinggungan dan kesesuaian antara upaya regenerasi yang sedang giat dilakukan oleh pembatik Kalimantan Tengah dengan pendapat pakar maupun data pustaka. Hasil penelitian berupa langkah-langkah yang dilakukan oleh pembatik terkait pelestarian batik tradisi dengan kearifan lokal disajikan berupa bagan.

\section{ANALISIS DAN INTERPRETASI DATA}

Kearifan lokal masyarakat Dayak memiliki beragam bentuk penerapan dan cara penyampaian. Implementasinya berupa tata nilai, perilaku melalui komunikasi verbal (ujaran) atau non verbal (melalui sistem atau simbolisasi pada benda pakai sehari-hari seperti busana, gaya hunian, dan pemilihan alat transportasi). Masyarakat Dayak memperoleh pendidikan dan pembelajaran pola asuh secara tidak langsung yang bersifat tradisional (turun temurun) untuk mengedepankan sopan santun dan budi pekerti. Terlihat dari cara berkomunikasi yang menggunakan lisan. Ungkapan-ungkapan khusus dan frasa-frasa digunakan dalam berkomunikasi untuk mempertegas makna. Pemakaian ungkapan tersebut biasanya untuk memberi nasehat atau mengkoreksi sikap negatif orang lain secara bijak.

Benang bintik merupakan nama lain dari batik khas Dayak Kalimantan Tengah. Dalam hal jenis, benang bintik tergolong ke dalam berbagai motif khas, di antaranya adalah motif batang garing (pohon kehidupan), motif huma betang, motif ukiran, motif senjata, motif naga, motif balanga, motif campuran dan motif-motif lainnya. Untuk warna dasar benang bintik memiliki warna yang lebih berani seperti warna merah maroon, biru, merah, kuning dan hijau. Ada juga bahan warna yang lebih 
gelap seperti hitam dan coklat. Bahan baku benang bintik umumnya menggunakan bahan kain jenis kain sutera, kain semi-sutera dan kain katun.

Ciri yang membuat khas batik Dayak Kalimantan Tengah ini di setiap motifnya selalu ada motif Batang Garing. Suku Dayak Ngaju memahami dunianya (kosmologi) melalui pemaknaan terhadap Pohon Batang Garing (pohon kehidupan). Pohon ini diyakini diturunkan langsung oleh Tuhan orang Dayak Ngaju yang bernama Ranying Hatalla Langit (Tuhan Yang Maha Esa). Dalam tetek-tatum (ratap tangis sejati) diceritakan bahwa Ranying Hatalla Langit menciptakan dua pohon yang diberi nama Batang Garing Tingang (pohon kehidupan) dan Bungking Sangalang.

Pohon Batang Garing berbentuk tombak dan menunjuk ke atas melambangkan Ranying Mahatala Langit. Bagian bawah pohon terdapat guci berisi air suci dan dahan berlekuk, yang melambangkan Jata atau dunia bawah. Sedangkan daun-daunnya melambangkan ekor Burung Enggang. Masing-masing dahan memiliki buah yang berjumlah tiga, menghadap ke atas dan ke bawah, melambangkan tiga kelompok besar manusia sebagai keturunan Maharaja Sangiang, Maharaja Sangen, dan Maharaja bunu atau buno.

Secara umum orang Dayak Ngaju memahami Batang Garing sebagai simbol tingkatan alam, yang terbagi menjadi tiga bagian besar, yaitu: 1. alam atas, 2. pantai danum kalunen (bumi), dan 3. alam bawah (air). Alam atas adalah tempat tinggal Ranying Hatalla Langit, bumi adalah tempat tinggal manusia, dan alam bawah adalah tempat tinggal jata atau lilih atau Raden Tamanggung Sali Padadusan Dalam atau Tiung Layang Raja Memegang Jalan Harusan Bulau, Ije Punan Raja Jagan Pukung Sahewan (Salilah, 1984).

Pengetahuan Suku Dayak Ngaju tentang alam, memberikan gambaran bahwa antara alam atas, bumi dan alam bawah merupakan satu kesatuan yang tidak dapat dipisahkan. Dari implikasi sosial yang ada, orang Dayak Ngaju begitu menghormati dan menghargai lingkungan alam tempat tinggal mereka. Apabila sudah ada tanda-tanda adanya ketidakselarasan hubungan antara manusia dengan alam, maka upacara adat Manyanggar dan ritual Hinting Pali (portal adat) itu bisa dilaksanakan dengan tujuan untuk menetralisir atau menyeimbangkan hubungan antara manusia dengan makhluk halus yang menghuni alam sekitarnya. Tanda-tanda alam tersebut, misalnya: seringnya terjadi musibah, sering ada pertikaian, panen banyak yang gagal, dan lain-lain (Usop, 2015).

Keyakinan dan pengetahuan terhadap pohon Batang Garing ini membawa implikasi/pengaruh ke dalam perilaku kehidupan sosial masyarakat Dayak Ngaju di Kalimantan Tengah, antara lain pengaruh pada pelaksanaan beberapa upacara tradisional (antara lain upacara adat Manyanggar), yang salah satu prosesnya dengan kegiatan menawur behas (menabur beras), yaitu menaburkan beras ke segala penjuru. Kenapa harus beras, karena beras berasal dari pantis kambang kabanteran bulan, lelek lumpung matanandau di bukit kagantung langit di langit ketujuh. Melalui beras sebagai duta komunikasi orang Dayak Ngaju dengan putir selong tamanang (roh putri dalam beras) dan raja angking langit yang diteruskan kepada Ranying Hatalla. Rasa hormat orang Dayak kepada beras bukan berarti mereka menyembah beras, namun karena beras mampu menjadi duta bagi mereka dengan Hatalla (Usop, 1994).

Sertifikasi batik sebagai produk budaya asli Indonesia yang dikeluarkan PBB melalui lembaga UNESCO merupakan momentum penting bagi perkembangan seni batik di Tanah Air. Citra positif batik di dunia internasional tersebut berlanjut di tanah air tatkala Presiden Republik Indonesia (RI) menetapkan tanggal 2 Oktober 2009 sebagai Hari Batik Nasional.

Kondisi tersebut memberikan dampak positif bagi pelaku usaha dan pengrajin kain batik di berbagai daerah di Indonesia, tak terkecuali Kalteng dengan motif kain batik "Benang Bintik" sebagai Motif Batik Khas Suku Dayak di Kalimantan Tengah.

Salah satu peluang ekonomi yang terbuka dari trend tersebut adalah pengembangan industri garmen Batik Benang Bintik di daerah. Industri kreatif ini memiliki potensi yang bagus.Beberapa waktu lalu, keharusan pemakaian Batik Khas Dayak Kalimantan Tengah (Benang Bintik) masih terbatas pada kegiatan formal seperti seragam sekolah dan kantor. Oleh karena itu, kesan Batik Benang Bintik kemudian lebih dikenal sebagai bahan busana dan pakaian resmi untuk upacara adat atau acara seremonial seperti pernikahan.

Kini, Batik benang bintik memang semakin dikenal, ragam busana dari motif kain Benang Bintik sering pula dipakai pada kegiatan-kegiatan seperti festival, ajang pemilihan model atau kegiatan kebudayaan dan kesenian daerah lainnya.

Di Kalimantan Tengah, terutama di Kota Palangka Raya sentra pembuatan dan percetakan kain batik Benang Bintik masih sangat minim. Pembuatan maupun percetakan Benang Bintik lebih banyak dilakukan di luar wilayah Kalimantan Tengah. Padahal cakupan wilayah permintaan pasarannya telah tersebar luas di seluruh Kalimantan Tengah. Bahkan, model-model pakaian Benang Bintik selalu tampak di beberapa sentra usaha penjahitan.

Keberlanjutan, pelestarian dan regenerasi batik tradisi masih terus berjalan dan diupayakan konsistensinya sampai hari ini di Kalimantan Tengah. Proses panjang dan hambatan dialami oleh pembatik senior yang mayoritas 
berusia lanjut menghasilkan cara menarik animo dari generasi muda untuk melanjutkan aktivitas batik tradisi. Hambatan terbesar adalah kesadaran untuk merasa memiliki, sebagaimana disebutkan pada poin satu ajaran huma betang. Kesadaran ikut memiliki disebutkan paling awal karena hal tersebut berkaitan dengan moral dan mental kuat dilandasi dengan pemahaman, bahwa tradisi merupakan harta tak ternilai yang membentuk budaya dan struktur sosial di Kalimantan Tengah. Batik Kalimantan Tengah merupakan bentuk sentra batik yang masih mempertahankan teknik tradisional untuk menghasilkan lembar kain kaya makna. Kegiatan membatik di Kalimantan Tengah bukan untuk kepentingan industri yang menuntut kuantitas, tetapi menjaga kualitas dengan rangkaian proses tradisi sebagai bagian dari kontemplasi masyarakat, khususnya para perempuan pembatik. Perputaran ekonomi yang lamban dari batik Kalimantan Tengah, menjadi salah satu penyebab keengganan generasi muda melanjutkan aktivitas tersebut. Batik Kalimantan Tengah memiliki konsep istimewa karena bukan sebagai penopang hidup, tetapi sebagai sarana ekspresi, kontemplasi, dan rekreasi untuk pembatik. Hasil karya yang belum laku, tidak menjadi soal bagi mereka, karena para pembatik tersebut memiliki keyakinan bahwa rejeki sudah diatur adil oleh Yang Maha Kuasa. Batik yang terjual berarti si kain telah menemukan jodohnya, sang pemilik. Kain batik dibuat sepenuh hati oleh tarian canting para pembatik tersebut. Sebalikya, ketika masih terpajang indah di kayu display, berarti tengah menunggu sang pemilik sedang dalam perjalanan untuk menjemput.

Bekerjasama dengan pemerintah daerah dan dinas pendidikan setempat, aktivitas membatik dimasukkan dalam kurikulum sebagai kegiatan ekstra kurikuler rutin. Beberapa pertimbangan digunakan sebagai dasar mengangkat membatik sebagai kegiatan tambahan, yakni membantu olah motorik halus pada anak, meningkatkan konsentrasi, pengendalian emosi, meningkatkan kepekaan terhadap olah bentuk, menjaga koordinasi sikap tubuh, menanamkan rasa cinta pada seni tradisi, dan menstimulasi untuk berkreasi mencipta motif-motif kontemporer Membatik juga melatih kesabaran, disiplin, dan keteraturan. Motif batik geometris misalnya, tidak boleh dibuat dengan melompat-lompat posisi sesuka hati, karena berpengaruh pada hasil akhir, tidak terlihat menyatu. Berdasarkan penuturan narasumber, pembatik yang sudah dapat menciptakan irama dalam mencanting kain, mampu memiliki daya imajinasi terhadap hasil akhir batikannya, baik/kurang secara estetik. Sinergi serta kolaborasi antara keluarga dan pihak sekolah berikut elemen masyarakat (pemerintah) merupakan daya dorong yang baik untuk keberlanjutan batik tradisi. Batik tradisi di Kalimantan Tengah menjadi media tepat untuk menghidupkan peran kearifan lokal pada nasehat sehari-hari masyarakat Kalimantan Tengah dan filosofih huma betang batang melambangkan untuk menjaga keseimbangan hubungan manusia dengah Tuhan, manusia dengan alam, dan hubungan manusia dengan sesama manusia harus harmonis dan masyarakat kalimantan tengah ada masyarakat yang terbuka tidak tertutup akan keberagaman suku dan agama bisa hidup rukum dan bertoleransi yang abadi dan relevan dengan kondisi terkini.

\section{SIMPULAN}

Temuan penelitian ini adalah rumusan cara pelestarian batik tradisi di Kalimantan Tengah dengan kekuatan efektifitas peran kearifan lokal masyarakat bersumber Kaharingan yang selalu menjaga keseimbangan kosmos. Batang garing tidak hanya berisi ajaran yang bernilai filosofis, tetapi menyangkut dimensi mikrokosmos untuk tiap-tiap individu masyarakat Dayak, serta makrokosmos di luar aktivitas di luar. Pada perkembangannya batik tradisi di Kalimantan Tengah membentuk dirinya sendiri dalam format kearifan lokal khas Kalimantan Tengah. Batik menjadi media untuk membentuk hubungan sosial dan komunikasi yang baik. Topik yang ringan namun memiliki muatan budaya sebagai identitas sebuah negara besar bernama Indonesia adalah batik. Masyarakat menjadi bukti pola pikir anti arus utama yang memposisikan batik sebagai komoditas ekonomi dan aktivitas penopang hidup. Batik tradisi Kalimantan Tengah merupakan sarana eskpresi, kontemplasi, dan rekreasi bagi masyarakat. Para perajin mampu mengembangkan macam-macam jenis, motif dan pakem penggunaaanya untuk pengembangan ke depan dengan memamhami nilai-nilai simbol dan tanda batang garing. Simbol pohon hidup kalpataru mempengaruhi pelakunya untuk menjaga sikap agar tidak melanggar adat dan menjaga keseimbangan alam menjadi ide motif batik.

Nilai-nilai positif pada batik benang bintik merupakan sarana efektif untuk menanamkan nilai-nilai ketekunan, disiplin, dan kesabaran. Tiga nilai tersebut menjadi modal dasar utama bagi generasi muda penerus bangsa. Usia dini dianggap tepat untuk melakukan upaya pelestarian. Pada usia tersebut anak hanya dituntut untuk mampu menguasai permainan dan tunduk pada aturan, sehingga masih terbuka ruang pada pola pikirnya untuk diafirmasi memori yang baik tentang pelestarian tradisi. Kunci keberhasilan regenerasi adalah pendekatan dan cara yang tepat untuk menyampaikan maksud, hingga tumbuhnya kesadaran serta inisisasi untuk melakukan tindakan nyata. Kearifan lokal masyarakat Dayak yang paling utama adalah kemampuan untuk beradaptasi menyesuaikan kemajuan zaman dan tetap menjaga sikap. Peran kearifan lokal masyarakat Dayak dalam halkemampuannya melestarikan batik tradisi yakni menumbuhkan kesadaran untuk merawat budaya, melalui pendekatan persuasif melalui nasehat, ajaran, nilai serta norma. Keterkaitan antara kearifan lokal dan nilai tradisi adalah berbanding lurus. Kearifan lokal yang terjaga dan masih dimanfaatkan oleh masyarakat sebagai panduan hidup otomatis terlihat dari implementasinya pada bentuk seni tradisi, dan seba- liknya. Pendekatan 
antropologi untuk menggali data dari masyarakat terkait kebudayaan, karena membebaskan masyarakat untuk memberikan beragam informasi mengalir dari berbagai perspektif. Kelemahan pendekatan ini adalah masyarakat memiliki bahasa tersendiri, sehingga kemampuan analisis dan interpretasi yang baik diperlukan guna menyajikan data dengan validitas baik. Penelitian ini masih memiliki peluang untuk dikembangkan dengan lokasi penelitian berbeda menggunakan tahapan yang sama. Lokasi berbeda akan menghasilkan variasi hasil berbeda. Hal tersebut disebabkan beragam faktor, terutama peraturan khusus yang berlaku di suatu wilayah.

\section{DAFTAR RUJUKAN}

Adnyani, N. W. Giri. (2017), Batik: The Colors of Life. Jakarta: Kementerian Pariwisata Republik Indonesia.

Amanda, Irine Carissa Desmaristi. (2018), "Identifikasi Bentuk-bentuk Kearifan Lokal dalam Sistem Religi Masyarakat Situs Sangiran Studi Kasus di Kecamatan Gondan- grejo, Karanganyar", in the Jurnal Sangiran, VII/1, Balai Pelestarian Situs Manusia Purba Sangiran, Sragen.

Astuti D., Siti Irene. (11 ${ }^{\text {th }}$ July 2012), "Kearifan Lokal sebagai Modal Sosial dalam Pendidikan Karakter di Sekolah", in the Seminar Nasional Ilmu Pendidikan Program Studi Ilmu Pendidikan Program Pascasarjana Universitas Negeri Makasar, di Gedung AD Lantai 5 PPs UNM.

Endraswara, Suwardi. (2018), Falsafah Hidup Jawa: Menggali Mutiara Kebijakan dari Intisari Filsafat Kejawen, Cakrawala, Yogyakarta.

Herdiana, Uung Runalan Soedarmo, \& Yadi Kusmayadi. (2020), "Motif Ragam Hias dan Nilai-nilai Filosofis Batik Ciamis", in the Jurnal Artefak, VII/1, 1-15, Program Studi Pendidikan Sejarah, Fakultas Keguruan dan Ilmu Pendidikan, Universitas Galuh, Ciamis.

Hutabarat, Edward. (1999), Busana Nasional Indonesia. Jakarta: PT. Karia Karia Cipta Mandiri.

Ihromi, T. O. (2004), Pokok-pokok Antropologi Budaya, Yayasan Obor Indonesia, Jakarta.

Kristie, Sella, Tessa Eka Damayanti, \& Sriwinarsih Maria Kirana. (2019), "Makna Motif Batik Parang sebagai Ide dalam Perancangan Interior", in the AKSEN Journal of Design and Creative Industry, III/2, 57-69, Interior Architecture Department Ciputra University, Surabaya.
Ningsih, Zain Rochmati. (2018), "Kearifan Lokal Masyarakat Jawa dalam Novel Genduk Sundari Mardjuki (Kajian Antropologi Sastra)", in the Jurnal Mahasiswa Unesa, I/1, 1-11, Program Studi Pendidikan Bahasa dan Sastra Indonesia, Jurusan Bahasa dan Sastra Indonesia Fakultas Bahasa dan Seni Universitas Negeri Surabaya, Surabaya.

Nurcahyanti, D., Sachari, A., \& Destiarmand, A. H. (2020). Peran Kearifan Lokal Masyarakat Jawa Untuk Melestarikan Batik Tradisi di Girilayu, Karanganyar, Indonesia. Mudra Jurnal Seni Budaya, 35(2), 145-153. https://doi.org/10.31091/mudra.v35i2.816

Pramono, Kartini. (2013), "Nilai Kearifan Lokal dalam Batik Tradisional Kawung", in the Jurnal Filsafat, XXIII/2, 134-146, Fakultas Filsafat Universitas Gadjah Mada, Yogyakarta.

Qiram, I., -, B., \& Rubiono, G. (2018). Batik Banyuwangi: Aesthetic and Technical Comparison of Coastal Batik. Lekesan: Interdisciplinary Journal of Asia Pacific Arts, 1(2), 79-85. https://doi.org/10.31091/lekesan.v1i2.407

Salilah, Yohanes, (1984), Aneka Ragam Ukiran dan Lukisan Dayak Ngaju Kalimantan Tengah, Lembaga Bahasa dan Seni Budaya, Universitas Palangka Raya, Palangka Raya.

Suarta, I. M. (2018). Nilai-nilai Filosofis Didaktis, Humanistis, dan Spiritual dalam Kesenian Tradisional Macapat Masyarakat Bali. Mudra Jurnal Seni Budaya, 33(2), 191-199. https://doi.org/10.31091/mudra.v33i2.364

Suminto, R. A. Sekartaji. (2015), "BATIK MADURA: Menilik Ciri Khas dan Makna Filosofinya", in the CORAK Jurnal Seni Kriya, IV/1, 1-12, Institut Seni Indonesia Yogyakarta, Yogyakarta.

Situngkir, Hoki. (2016), Kode-kode Nusantara, Exposé, Jakarta Selatan.

Suparlan, Parsudi, (2004), Hubungan antar-sukubangsa. Yayasan Pengembangan Kajian Ilmu Kepolisian, Jakarta. Tabrani, Primadi. (2012), Bahasa Rupa, Kelir, Bandung.

Usop, KMA M, (1994), Pakat Dayak Sejarah Integrasi dan Jatidiri Masyarakat Dayak dan Daerah Kalimantan Tengah, Yayasan Pendidikan dan Kebudayaan Batang Garing, Palangkaraya. 
Usop, Linggua Sanjaya, (2015), “Maniring Hinting sebagai Gerakan Kontra Hegemoni Masyarakat Dayak dalam Pembertahanaan Hak-hak atas Tanah di Kotawaingin Timur". Disertasi, Program Pascasarjana, Universitas Udayana.

Wahida, A., Handayani, E. S., \& Supriyadi, S. (2020). The Philosophical Values of Kawung Batik Motif in Contemporary Batik Painting. Mudra Jurnal Seni Budaya, 35(1), 76-82. https://doi.org/10.31091/mudra.v35i1.1001

Wiranata, I Gede A. B. (2011), Antropologi Budaya, PT Citra Aditya Bakti, Bandung. 